\title{
Longevity of Sclerotinia sclerotiorum sclerotia on the soil surface under field conditions
}

\author{
Ricardo Brustolin, Erlei Melo Reis \& Lucas Pedron
}

Laboratório de Fitopatologia, Faculdade de Agronomia e Medicina Veterinária, Universidade de Passo Fundo, 99001-970, Passo Fundo, RS, Brasil

Autor para correspondência: Ricardo Brustolin (ricardo.brustolin@pioneer)

Data de chegada: 06/10/2015. Aceito para publicação em: 27/11/2015.

$10.1590 / 0100-5405 / 2131$

\section{ABSTRACT}

Brustolin, R.; Reis, E. M.; Pedron, L. Longevity of Sclerotinia sclerotiorum sclerotia on the soil surface under field conditions. Summa Phytopathologica, v.42, n.2, p.172-174, 2016.

The longevity of Sclerotinia sclerotiorum sclerotia was quantified in an experiment carried out in the field. Sclerotia naturally formed in soybean plants in an infested commercial field were collected in a grain-cleaning machine and those present in the stem pith, with c.a. $8 \mathrm{~mm}$ in length and $1.9 \mathrm{~mm}$ in diameter were selected. Fifty sclerotia were kept inside a white nylon mesh $(0.25 \mathrm{~mm})$ screen bag $(25 \times 25 \mathrm{~cm})$. Eighty bags were laid on the soil surface-simulating no till farming. At monthly intervals, four bags were taken and brought to the laboratory. Sclerotia were washed with tap water and surface desinfested with sodium hypochlorite and exposed to germinate on sterilized moist river sand in a growth chamber at $15^{\circ} \mathrm{C}$ and $12 \mathrm{~h}$ photoperiod. After 12 months, sclerotia kept on the soil surface, lost their viability. It may be concluded that under no till, crop rotation with nonsusceptible crops, can reduce the sclerotia bank in the soil.

Keywords: Survival, resting structure, dormancy, soybean white mold.

\section{RESUMO}

Brustolin, R.; Reis, E. M.; Pedron L. Longevidade de escleródios de Sclerotinia sclerotiorum na superfície do solo no campo. Summa Phytopathologica, v.42, n.2, p.172-174, 2016.

Em experimento conduzido no campo quantificou-se o período de viabilidade de escleródios de Sclerotinia sclerotiorum. Escleródios naturalmente produzidos em plantas de soja numa lavoura comercial foram coletados numa máquina de pré-limpeza. Utilizou-se no trabalho os escleródios produzidos na medula das plantas e com tamanho de aproximadamente oito $\mathrm{mm}$ de comprimento e $1,9 \mathrm{~mm}$ de diâmetro. Cinquenta escleródios foram acondicionados num recipiente feito com tela de nylon branca $(25 \times 25 \mathrm{~cm})$ com malha de $0,25 \mathrm{~mm}$. Oitenta recipientes foram posicionados na superfície do solo simulando o plantio direto. Mensalmente foram removidos quatro recipientes. $\mathrm{O}$ solo aderido às embalagens foi removido com jato d'água de torneira, os escleródios lavados, submetidos à assepsia com hipoclorito de sódio e postos a germinar em areia de rio esterilizada, em câmara de crescimento a $15^{\circ} \mathrm{C}$ e fotoperíodo de $12 \mathrm{~h}$. Os escleródios, mantidos na superfície do solo, perderam a viabilidade em 12 meses. Conclui-se que o banco de escleródio no solo, sob plantio direto, pode ser reduzido pela rotação de culturas com espécies vegetais não suscetíveis.

Palavras-chave: sobrevivência, estrutura de repouso, dormência, mofo-branco soja.

The soybean [Glycine $\max (\mathrm{L}$.$) Merr.] area attacked by white$ mold (WM) caused by Sclerotinia sclerotiorum (Mont.) De Bary, is approximately 6.3 million ha (Meyer - personal communication). WM is one of the most destructive plant diseases around the world. The damage function in soybeans, average of nine experiments, was $\mathrm{Y}=1,000$ to $6.7 \mathrm{I}(\mathrm{Y}=$ grain yield normalized to $1,000 \mathrm{~kg} / \mathrm{ha}$ and $\mathrm{I}=$ incidence in plants) (14).

Sclerotinia sclerotiorum (Ss) is among the most nonspecific, omnivorous plant pathogenic fungi that can occur on many continents and has a wide host range of plants (nt.ars-grin.gov/fungaldatabases/ index.cfm).

A key characteristic of this pathogen is its ability to produce black resting structures known as sclerotia and white cottony growths of mycelium on the infected plants. The esclerotium is an aggregation of hyphae forming a black exterior shell with several melanized cell layers important in its protection from adverse conditions and microbial degradation $(3,10)$. Thus, the sclerotia play an important role in the disease cycle, being the main structures for a long-term survival (17).

During a growing season, sclerotia in infested fields germinate by producing mycelia or apothecia. Infections are initiated by mycelia arising from the sclerotia, i.e. in sunflower, or by airborne ascospores produced in apothecia to infect crops such as canola, beans and soybeans $(1,17)$.

In Brazil, the dormant structures, germinate regardless of the host plant presence, throughout the year, causing disease in the winter (canola and forage rape), in spring (sunflower) and in summer (edible beans and soybean) crops (4). Thus, sclerotia bank in the soil can be increased throughout the year due to the fungus multiplication in this range of susceptible hosts.

The longevity of sclerotia in the soil varies widely according to different authors. They can remain viable for up to eight years when in the soil (2); at least for three years (7); for 3-5 years $(12,15)$; for 11 


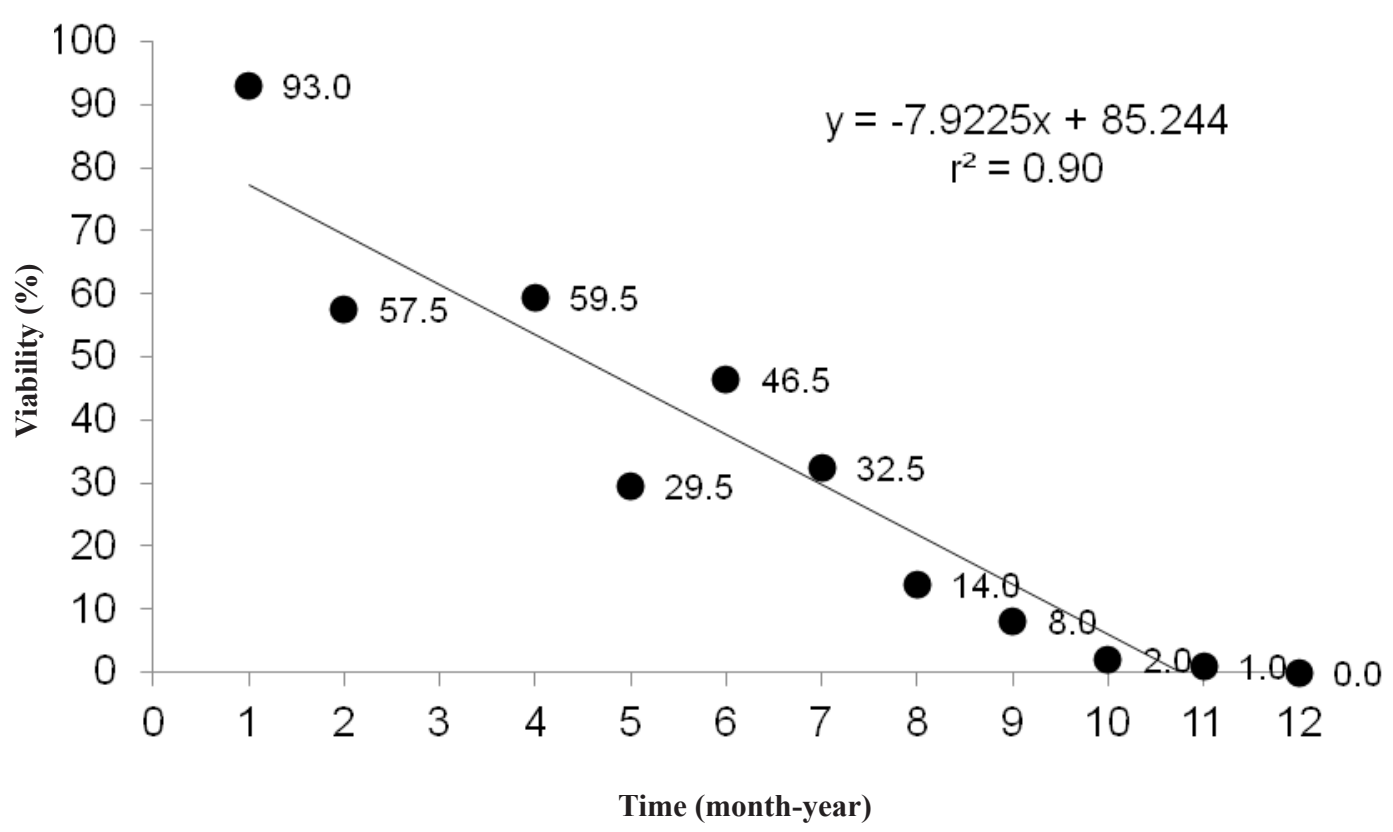

Figure 1. Longevity of Sclerotinia sclerotiorum sclerotia on the soil surface under natural field conditions. Dots are means of four replications.

Table 1. Monthly means temperature and total rain during the experiment

\begin{tabular}{cccc}
\hline Month/year & $\begin{array}{c}\text { Temperature } \\
\left({ }^{\circ} \mathbf{C}\right)\end{array}$ & $\begin{array}{c}\text { Rain } \\
(\mathbf{m m})\end{array}$ & $\begin{array}{c}\text { Rain } \\
(\mathbf{m m}) \\
\text { (8 years means) }\end{array}$ \\
\hline Apr-11 & 18.4 & 108.8 & 165.0 \\
May-11 & 14.1 & 137.1 & 170.5 \\
Jun-11 & 11.4 & 226.7 & 163.4 \\
Jul-11 & 12.4 & 340.0 & 172.9 \\
Aug-11 & 13.3 & 253.9 & 138.0 \\
Sep-11 & 15.4 & 47.3 & 189.7 \\
Oct-11 & 18.3 & 194.7 & 225.3 \\
Nov-11 & 20.2 & 77.1 & 183.4 \\
Dec-11 & 21.2 & 91.2 & 151.7 \\
Jan-12 & 22.1 & 105.2 & 136.1 \\
Feb-12 & 23.6 & 86.0 & 142.3 \\
Mar-12 & 20.7 & 114.5 & 122.3 \\
Apr-12 & 20.5 & 23.2 & 165.0 \\
\hline Mean & $\mathbf{1 7 . 8}$ & $1,805.7$ & $2,125.6$ \\
\hline
\end{tabular}

years (11); at least two years (6). Davis (8) found that sclerotia of Ss near the soil surface do not remain viable for over a year. The survival time of Ss in natural field varied with soil depth, greater when they were buried at $10 \mathrm{~cm}$ (34 months) than those kept on the soil surface (13 months). Their monthly viability was represented by the equations $y=-2.5086 x+96.205\left(R^{2}=0.97\right)$, and $y=-6.071982785\left(R^{2}=0.99\right)$ buried and at the soil surface respectively (13).

This study aimed to determine the longevity of Ss sclerotia on the soil surface, under field conditions, simulating no till farming following the same methodology (13).

In the experimental field of University of Passo Fundo coordinates are $28^{\circ} 13^{\prime} 35.05$ 'S and 52 23 '35.56”'W, and $698 \mathrm{~m}$ above sea level.

Sclerotia naturally produced in commercial soybean crop were collected in a pre-cleaning machine. Only sclerotia produced in the pith of the plants with approximately eight $\mathrm{mm}$ in length and $1.9 \mathrm{~mm}$ in diameter were used in the work. Fifty sclerotia were introduced in a bag made of a white nylon $0.25 \mathrm{~mm}$ mesh and measuring $25 \times 25 \mathrm{~cm}$. Expecting the Ss survival for a long period of time a total of 80 bags were prepared to last for 20 months. On April 2011, they were taken to the field and laid on the soil surface under soybean crop residues soon after harvest, simulating zero tillage. Bags were deposited in line of 20, with four replications and the position of each one marked with an aluminum wire ( $4 \mathrm{~mm}$ diameter, $25 \mathrm{~cm}$ long). In the winter the area was cultivated with black oats (Avena strigosa, Shreb) as a mulching crop. In the summer, the area was cultivated again with soybeans and the bags placed in the soybean planting rows.

At monthly intervals, four bags were collected, taken to the laboratory. Sclerotia were cleaned with tap water to remove soil particles, surface desinfested with an aqueous solution of sodium hypochlorite $2.75 \%$, rinsed in distilled sterile water, and placed to germinate on washed sterilized river sand, in acrylic boxes $(11 \times 11 \mathrm{~cm}$ side and $3.3 \mathrm{~cm}$ high) and kept in a growth chamber (Biological Oxygen Demand) at $15^{\circ} \mathrm{C}$ and a $12-\mathrm{h}$ photoperiod. Some collected sclerotia were soft, other empties with only the outer layer of melanin present. The amount of these structures in the bags was decreasing as time passed.

Under the incubation conditions sclerotia were observed for a period of 45 days and only sclerotia that germinated and formed apothecia were considered viable.

Data were submitted to linear regression analysis.

In the present work was determined how much time was required to eliminate the Ss inoculum on the soil. It is also important to know when a susceptible crop, such as soybean, can return to be cultivated in the previously infested area. These results can be useful to determine the rotation period, or the lapse between cultivation of susceptible hosts in the area to control WM by reducing or eliminating Ss sclerotia bank in the soil. 
Sclerotia germinate in the absence of a susceptible host. According to Abawi \& Grogan (1) soil water content, temperature and light are the most important factors for Ss carpogenic germination, thus not requiring the host presence. Germination of Ss sclerotia can be stimulated by covering the soil with a mulch crop such as Brachiaria sp. to supply enough moisture required for germination (9).

As time was passing by, there was a linear decline in sclerotia viability. At the time of each collect, it was observed that most of sclerotia had germinated while those still dormant remained hard without stipe. After 12 months, on June $11^{\text {th }}, 2012$, sclerotia viability reached zero (Fig. 1) much shorter than some references $(2,6,7,11$, 12, 15, 11); Davis (8), but similar to Reis \& Tomazini's (13) report. The straight line of Ss survival was represented by the equation $\mathrm{y}=$ $-7,9225 x+85,244$ with $r^{2}=0.90$ (Fig. 1). Viability decreases at a rate of $7.9 \%$ per month.

Several factors are involved in the sclerotia germination. Ferraz et al. (9) reported that the soil moisture content and frequency of irrigation, directly affect the carpogenic germination. The same authors made reference that the disease caused by $S s$ in edible bean, is lower in no-till than in conventional tillage and discuss the possibility of the residues effect as a physical barrier to the stipes emergence and/or ascospores released into the air. In addition, several other mechanisms are involved with the sclerotia loose of viability in a shorter time under no till. The sclerotia at soil surface, simulating no-till, in the presence of light, germinate and lost viability faster than those buried in the soil (13).

The resting structures survival in soil can be affected by several factors including the soil water content, soil depth, wetting and drying alternation (8). Moreover, the resting structures require light as a stimulus for germination (16), i.e. those at soil surface germinate earlier than those buried and in the absence of the light.

Similarly, to the weeds seed bank in the soil (5), there is a similar bank of Ss sclerotia in the soil (15). In southern Brazil, the sclerotia are produced by all susceptible hosts in the winter, spring and summer. Thus, always and constantly, they germinate, fulfilling its biological function. At harvest of cultivated species, or weeds senescence, they fall to the ground, and again the inoculum density can be increased or replaced, which had declined from the harvest time of susceptible crops to the next sowing time. If there is no replacement, the sclerotia lose viability and the bank can reach zero as shown in our work.

The diseases caused by Ss are considered difficult to be controlled because the fungus can remain viable in soil for a long period of time $(2,6,7,11,12,15)$, and therefore would not be controlled by short time crop rotation.

This work confirms the Reis and Tomazini's (13) findings which work was carried in the same site and with same methodology. It has been reported sclerotia longevity as long as 11 years, 10 years, or 8 years and we have found 12 months similar to Reis and Tomazini (13).

During the time this work was conducted, weather was drier $(1,805.7 \mathrm{~mm})$ than the mean rainfall of the last eight $\mathrm{y}$ seasons $(2,125.6 \mathrm{~mm})$. Most of the months were drier than the eight seasons means but enough to ensure sclerotia germination. The minimum
11.4, maximum 23.6 , and average mean air temperature $17.8^{\circ} \mathrm{C}$ can be considered favorable for sclerotia germination (Table 1).

We can infer that soybean WM can be controlled by crop rotation with non-susceptible crops for a period longer than 12 months.

\section{REFERENCES}

1. Abawi, G.S.; Grogan, R.G. Epidemiology of diseases caused by Sclerotinia species. Phytopathology, St. Paul, v.69, n. 8, p.899-903, 1979.

2. Adams, P. B.; Ayers, W. A. Ecology of Sclerotinia species. Phytopathology, St. Paul, v. 69, n. 8. p. 896-899, 1979.

3. Bell, A.A.; Wheeler, M.H. Biosynthesis and functions of fungal melanins. Annual Review of Phytopathology, Palo Alto, v.24, p. 411-451, 1986.

4. Brustolin, R.; Rossi, R.L.; Reis, E.M.; Mofo branco. In: Reis, E.M.; Casa, R.T. (Org.). Doenças da soja. Passo Fundo: Berthier, 2012. p. 217 - 232.

5. Carmona, R. Problemática e manejo de bancos de sementes de invasoras em solos agrícolas. Planta Daninha, Vicosa, v.10, n.1/2, p.5-16, 1992.

6. Coley-SmitH, J. R.; Cooke, R. C. Survival and germination of fungal sclerotia. Annual Review of. Phytopathololgy. Palo Alto, v.9, p.6592, 1971.

7. Cook, G.E.; Steadman, J.R.; Boosalis, M.G. Surviral of Whetzelinia sclerotiorum and initial infection of dry edible beans in western Nebraska. Phytopathology, St. Paul, v.65, p. 250 - 255, 1975.

8. Davis, W. H. Drop of Chinese cabbage and our common cabbage caused by Sclerotinia sclerotiorum (Lib.) De Bary, (Sclerotinia libertiana Fckl.). Phytopathology, St. Pail, v. 15, p. 249-259, 1925.

9. Ferraz, L. C. L.; Café-Filho, A. C.; Nasser, L. C. B.: Azevedo, J. Effects of soil moisture, organic matter and grass mulching on the carpogenic germination of sclerotia and infection of bean by Sclerotinia sclerotiorum. Plant Pathology, Reading, v. 48, n.7. p.77-82, 1999.

10. Henson, J.M.; Butler, M.J.; Day, A.W. The dark side of mycelium: melanins of phytopathogenic fungi. Annual Review of Phytopathology, Palo Alto, v. 37, p. 447-471, 1999.

11. Leite, R.M.V.B.C. Ocorrência de doenças causadas por Sclerotinia sclerotiorum em girassol e soja. Londrina: Embrapa Soja, 3p. (Comunicado Técnico 76), 2005.

12. MClean, D. M. Some experiments concerned with the formation and inhibition of apothecia of Sclerotinia sclerotiorum (Lib.) D. By. Plant Disease, St Paul, v.42, p. 409-412, 1958.

13. Reis, E. M.; Tomazini, S. L. Viabilidade de escleródios de Sclerotinia sclerotiorum, no campo, em duas profundidades do solo. Summa Phytopathologica, Botucatu, v. 31, n. 1, p. 97-99, 2005.

14. Reis, E.M.; Zanatta, M.; Campos, H.D.; Silva L.H.C.P.; Meyer, M.C.; Nunes, J.N.; Pimenta, C.B.; Cassetari Neto, D.; Machado, A.Q.; Juliatti, F.C.; Utiamada. C.M. Critical-point yield model to estimate grain yield damage caused by Sclerotinia sclerotiorum in soybean. Summa Phytopathologica, Botucatu, 2011. Suplemento.

15. Schwartz, H. F.; Steadman, J.R. Factors affecting sclerotium populations of, and apothecium production Sclerotinia sclerotiorum. Phytopathology, St. Paul, v. 68, p. 383-388, 1978.

16. Sun, O.; Yang, X.B. Ligth, temperature, and moisture effects on apothecium production of Sclerotinia sclerotiorum. Plant Disease, St. Paul, v. 84, p. 1287-1293. 2000

17. Willetts, H.J.; Wong, J.A. The biology of Sclerotinia sclerotiorum, S. trifoliorum, and S. minor with emphasis on specific nomenclature. Botanical Review, New York, v. 46, p. 101-165, 1980. 